\title{
DNA Methylation from Bloodstain as a Forensic Age Estimation Method
}

\author{
Ahmad Yudianto, ${ }^{1,5,6}$ Masniari Novita, ${ }^{3}$ Muhammad Afiful Jauhani, ${ }^{2,4}$ Deka Bagus Binarsa ${ }^{2}$ \\ ${ }^{1}$ Department of Forensic Medicine and Medicolegal, Faculty of Medicine, Universitas Airlangga, Surabaya, \\ Indonesia, ${ }^{2}$ Resident of Forensic Medicine and Medicolegal Specialist Program, Faculty of Medicine, Universitas \\ Airlangga, Surabaya, Indonesia, ${ }^{3}$ Faculty of Dentistry, Universitas Jember, Indonesia, ${ }^{4}$ Faculty of Medicine, \\ Universitas Jember, Indonesia, ${ }^{5}$ Forensic Science Program, Postgraduate School Universitas Airlangga, Surabaya, \\ Indonesia, ${ }^{6} \mathrm{Human}$ Genetic Laboratory, Institute of Tropical Disease, Universitas Airlangga, Surabaya, Indonesia
}

\begin{abstract}
Forensic identification is an effort to help law enforcement officers to reveal a person's identity. Personal identity is often a problem in criminal and civil cases as well as cases related to death without identity and mass disasters. Age estimation is very important in forensic identification. DNA methylation is a potential epigenetic modification for age estimation because the aging process of DNA resembles the developments regulated in processes that are tightly controlled by specific epigenetic modifications. In most cases of violent crime, bloodstains can be found at the crime scene. Bloodstain may come from victims, perpetrators of crime, or both. Bloodstain can be used to scientifically reveal the correlation between DNA methylation from bloodstain and the age of unknown person. This study aimed to determine the correlation betweeen DNA methylation from bloodstain and a person's age. The study was conducted at the Institute of Tropical Disease of Universitas Airlangga from July to October 2019 using the analytic observational approach on 10 samples consisting of 5 male and 5 female samples. It was discovered that the correlation coefficient between DNA methylation and age in male subjects was 0.888 with a significance value of 0.04 and 0.834 in female subjects with a significance value of 0.079 . In conclusion, there is a significant correlation between percent methylation and age in male subjects. However, this correlation is not statistically significant in female subjects.
\end{abstract}

Key words: Age, bloodstain, DNA methylation, estimation, forensic

\section{Metilasi DNA pada Bercak Darah sebagai Metode Forensik untuk Perkiraan Umur}

\begin{abstract}
Abstrak
Identifikasi dalam bidang kedokteran forensik adalah upaya untuk membantu penegak hukum dalam menentukan identitas seseorang. Identitas personal sering menjadi masalah dalam kasus pidana, kasus perdata, kematian tanpa identitas, dan bencana massal. Estimasi umur sangat penting dalam identifikasi forensik. Metilasi DNA merupakan suatu modifikasi epigenetik yang potensial untuk memperkirakan umur. Hal ini dikarenakan, DNA pada individu yang mengalami penuaan menyerupai perkembangan yang diatur dalam proses yang dikontrol ketat oleh modifikasi epigenetik khusus. Pada kebanyakan kasus kriminal dengan tindak kekerasan, bercak darah dapat ditemukan pada tempat kejadian perkara. Bercak darah tersebut mungkin berasal dari korban, pelaku kejahatan, atau bahkan dari keduanya. Bercak darah dapat digunakan untuk membantu mengungkap peristiwa tersebut secara ilmiah Sejauh ini korelasi metilasi DNA dari bercak darah dengan umur seseorang belum banyak diketahui. Penelitian bertujuan mengetahui korelasi metilasi DNA dari bercak darah dengan umur seseorang. Penelitian dilakukan di Institute of Tropical Disease Universitas Airlangga periode Juli sampai Oktober 2019. Metode penelitian yang digunakan observasional analitik yang dilakukan pada 10 sampel dengan rincian 5 sampel pria dan 5 sampel wanita. Hasil penelitian, korelasi metilasi DNA dengan umur pada subjek laki-laki didapatkan nilai r adalah 0.888 dengan nilai signifikansi 0.04 dan pada subjek perempuan didapatkan r adalah 0.834 dengan nilai signifikansi 0.079. Simpulan ditemukan korelasi signifikan antara persen metilasi dengan umur pada subjek laki-laki, sedangkan pada subjek perempuan tidak terdapat korelasi yang signifikan secara statistik.
\end{abstract}

Kata kunci: Bercak darah, forensik, metilasi DNA, perkiraan, umur

Corresponding Author: M. Afiful Jauhani, Resident of Forensic Medicine and Medicolegal Specialist Program, Faculty of Medicine, Universitas Airlangga, Jl. Mayjen. Prof. Dr. Moestopo 47, Surabaya 60132, East Java, Indonesia. Email: afifuljauhani@gmail.com 


\section{Introduction}

Identification in the field of forensic medicine is an effort to support the law enforcement in determining a person's identity. Personal identity is a frequent case problem in criminal cases, civil cases, death without identity, and mass disasters. ${ }^{1}$ Primary data used in the identification are fingerprints, dental records, and deoxyribonucleic acid (DNA). ${ }^{2}$ Age estimation is very important in forensic analysis, which is often performed based on the analysis of bones and teeth. However, identification of bones and teeth can only be done when human skeletons are available identification. ${ }^{2}$ Dental records are still rarely performed in this country, thus the most possible primary data for identification is DNA. $^{3}$

The accuracy of the identification method in terms of estimating the age of the individual through the examination of biological evidence is essential to provide important guidance for law enforcement to trace the identity of unidentified persons. ${ }^{4}$ Developing tests for estimating age presents a challenge for scientists and practitioners in forensic medicine because the test must be applicable and valid despite the small amount of sample or degraded sample of various tissues and body fluids used. As a first step, a reliable age prediction model must be generated. ${ }^{5}$ Since recent studies have shown that human aging is related to changes in DNA methylation in specific location genomes, this epigenetic modification can be used to estimate an individual's age. ${ }^{6}$

DNA methylation is the best epigenetic modification that can be used to estimate the age of biological samples in humans. This is because DNA in aging individuals resembles the regulated development process that is tightly controlled by specific epigenetic modifications. This epigenetic modification process is only found at the position 5 of the pyrimidine ring of cytosine in the order of 5'-Cytosin-phosphateGuanin-3 '(CpG) dinucleotide. 5-Methylcytosine from several CpG peaked in genomic DNA can be replicated during cell division by maintaining certain DNA methyltransferases (DNMT) as the mediation in that DNA. ${ }^{3}$

Bloodstains are one of the most frequently biological samples in forensic laboratories because blood can easily be retrieved in almost all forms of violence. The investigation of bloodstains is very useful to uncover a crime. In most criminal cases, bloodstains can be found at the crime scene that may come from victims, perpetrators of crime, or even from both. Blood is an important biological evidence because it is a biological sample with potential properties that are specific to certain human groups that it can be used to help reveal the event scientifically. ${ }^{7}$ Based on these problems, this study aims to determine the estimated age using DNA methylation on bloodstain.

\section{Methods}

This study was conducted at the Human Genetic Laboratory, Institute of Tropical Disease, Universitas Airlangga, Indonesia during the period of July to October 2019. The ethical clearance was issued by the Health Research Ethical Clearance Commission Faculty of Dental Medicine Universitas Airlangga under ethical clearance number: 527/HRECC.FODM/VII/2019.

This was an observational laboratory study on a total of 10 samples with different ages from each sex. Bloodstains were dissolved in $0.9 \%$ $\mathrm{NaCl}$ in a $15 \mathrm{~mL}$ Falcon tube then centrifuged at 6000rpm for 20 minutes. DNA Extraction and Isolation were performed using the Invitrogen ${ }^{\mathrm{TM}}$ DNAzol ${ }^{\mathrm{TM}}$ Reagent.

The results of DNA extraction then underwent the bisulfite conversion process using the EZ DNA Methylation-Gold ${ }^{\mathrm{TM}}$ kit from Zymo Research. The result of the bisulfite conversion then underwent electrophoresis using 1\% agarose gel and amplification using PCR using GoTaq® Green Master Mix from Promega. The PCR products were sequenced using Applied Biosystems 3130 XL Genetic Analyzers to identify CpG sites and the results were analyzed with Bioedit $\AA$. CpG Island can be calculated using the Emboss CpGplot online application on the website http://www.ebi.ac.uk/Tools/seqstats/emboss cpgplot/. Percent methylation was determined by dividing the number of $\mathrm{CpG}$ islands by the number of sequences. The correlation between percent methylation and age was analyzed using the correlation test with the IBM SPSS Statistics 24 program.

\section{Results}

DNA from bloodstains are illustrated in Table 1 below. Data are presented according to the UV light absorption spectrophotometer measurements at $260 \mathrm{~nm}$ and $280 \mathrm{~nm}$ optical densities.

Based on the Table 1, the lowest DNA level 
Ahmad Yudianto, et al.: DNA Methylation from Bloodstain as a Forensic Age Estimation Method

Table 1 UV Spectrophotometer Results

\begin{tabular}{ccccc}
\hline Sample & OD 260 & 0D 280 & Concentration $(\boldsymbol{\mu g} / \boldsymbol{\mu l})$ & Purity \\
\hline A & 0.238 & 0.206 & 833 & 1.16 \\
B & 0.213 & 0.188 & 745.5 & 1.13 \\
C & 0.3 & 0.256 & 1050 & 1.17 \\
D & 0.454 & 0.372 & 1589 & 1.22 \\
E & 0.436 & 0.363 & 1526 & 1.20 \\
F & 0.312 & 0.267 & 1092 & 1.17 \\
G & 0.233 & 0.196 & 815.5 & 1.19 \\
H & 0.295 & 0.249 & 1032.5 & 1.18 \\
I & 0.165 & 0.145 & 577.5 & 1.14 \\
J & 0.481 & 0.393 & 1683.5 & 1.22 \\
\hline
\end{tabular}

was $577.5 \mu \mathrm{g} / \mu \mathrm{L}$ and the highest was $1683.5 \mu \mathrm{g} /$ $\mu \mathrm{L}$. The average level of DNA in blood spots was $1094.45 \mu \mathrm{g} / \mu \mathrm{L}$. The lowest DNA purity value was 1.13 and the largest purity value was 1.22 . The average value of DNA purity in blood spots was 1.18.

After bisulfite conversion, samples underwent methylation and PCR visualization using agarose $1 \%$ gel to see the presence or absence of DNA. From the results of visualization using agarose gel electrophoresis, 10 sample bands were obtained, ranging between $150 \mathrm{bp}$ and $300 \mathrm{bp}$. Results of DNA methylation were then sequenced using Applied Biosystems 3130 XL Genetic
Analyzers in the form of FASTA to calculate the percent methylation using Emboss CpGplot (http://www.ebi.ac.uk/Tools/seqstats/emboss_ cpgplot/). The results of the percent methylation calculation are presented in Table 2.

Data analysis using IBM SPSS Statistics 24 for male subjects revealed the r count value (Pearson Correlation) of 0.888 with a 2 -tailed significance value of 0.04 . Based on the $\mathrm{R}$ table, the $\mathrm{R}$-value for $n=5$ with a significance of $5 \%$ was identified as 0.878 . Because $r$ counts were higher than the $r$ tables and the significance value was less than 0.05 , it was concluded that there was a significant correlation between percent methylation and age

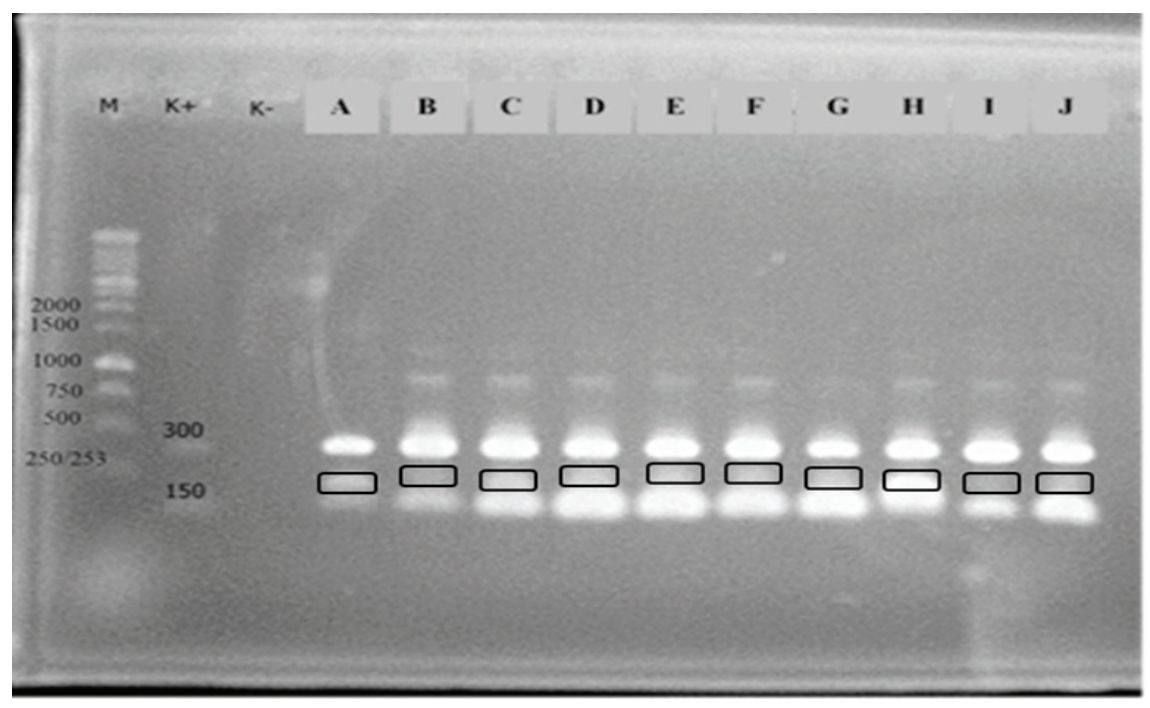

Figure Electrophoresis Results in 1\% Agarose Gel

$\mathrm{M}=\mathrm{DNA}$ marker $1 \mathrm{~Kb}$ K+ = Positive control K562; K- =Negative control aquadest; $\mathrm{A}=2$ years old male; $\mathrm{B}=6$ years old male; $C=20$ years old male; $D=42$ years old male; $E=47$ years old male; $F=4$ years old female; $G=11$ years old female; $\mathrm{H}=17$ years old female; $\mathrm{I}=34$ years old female; $\mathrm{J}=53$ years old female 
Table 2 Percent Methylation at 300 bp

\begin{tabular}{cclccc}
\hline Sample code & $\begin{array}{c}\text { Age } \\
\text { (years old) }\end{array}$ & Gender & CpG site & Sequence & $\begin{array}{c}\text { Percent Methylation } \\
\text { (\%) }\end{array}$ \\
\hline A & 2 & Male & 0 & 309 & 0 \\
B & 6 & Male & 202 & 691 & 29,23 \\
C & 20 & Male & 257 & 694 & 37.03 \\
D & 42 & Male & 434 & 829 & 52.35 \\
E & 47 & Male & 359 & 695 & 51.65 \\
F & 4 & Female & 22 & 199 & 11.05 \\
G & 11 & Female & 221 & 694 & 31.84 \\
H & 17 & Female & 80 & 199 & 40.20 \\
I & 34 & Female & 93 & 199 & 46.73 \\
J & 53 & Female & 358 & 728 & 49.18 \\
\hline
\end{tabular}

in male subjects. In female subjects, the $\mathrm{r}$ count (pearson correlation) was 0.834 with a 2 -tailed significance value of 0.079 . Since the r count was higher than $r$ tables but the significance value was more than 0.05 , it was concluded that there was no significant correlation between percent methylation and age in female subjects.

\section{Discussion}

In this study, the lowest and the highest DNA levels were $577.5 \mu \mathrm{g} / \mu \mathrm{L}$ and $1683.5 \mu \mathrm{g} / \mu \mathrm{L}$ respectively, while the average level of DNA was $1094.45 \mu \mathrm{g} / \mu \mathrm{L}$. The optimum DNA level needed for optimum results in bisulfite conversion is 200-500 ng. ${ }^{8}$ DNA isolated from bloodstains in this study were optimum for bisulfite conversion.

Percent methylation in male subjects tended to increase with age categorization but percent methylation actually decreases in elderly subjects. This is very likely influenced by lifestyle and environmental factors as well as illnesses. Whereas in female subjects, the percent methylation consistently increased with age categorization, although the rate of increase was not constantly measurable.

When males and females were compared, the $\mathrm{CpG}$ sites of the two sexes had significantly different levels of DNA methylation. This CpG site is located in an autosomal chromosome with absolute differences in methylation because the $\mathrm{CpG}$ site is located on the X chromosome, thus differences in sex-specific methylation of the $\mathrm{X}$ chromosome tend to be more unstable. Women's susceptibility to stress and certain diseases also greatly affect the rate of DNA methylation, hence the factors that affect DNA methylation vary greatly between individuals. ${ }^{9}$ Degenerative diseases and metabolic syndromes of each individual also greatly affect the results of percent methylated DNA. The process during the course of degenerative diseases targets elements of the cellular epigenetic machine, changing the expression and activity of the epigenetic machine which will affect changes in the epigenetic state of each individual. ${ }^{10}$

The epigenome regulator which is often neglected is neuroendocrine, whereas DNA methylation can be a dynamic process where the individual hormonal state greatly influences the role of hydroxymethylation of cytosine. The use of certain drugs with oxidative and antioxidant natures will also have an effect on the rate of histone modification. This can occur, for example, through cytosine mutations in cases where they are methylated in normal cells. The methylated cytosine absence can cause modification of permissive histone and allow genes to be expressed. This mechanism can change the phenotype and behavior of cells. ${ }^{10}$ Neoplastic, degenerative, metabolic, and even inflammatory diseases will cause oxidative stress which will affect the activation and inactivation of certain genes as well as genome instability and also occurs with epigenetic mechanisms. Unlike genetic mutations, epimutation does not change the basic sequence of DNA and is potentially reversible. ${ }^{10}$

From this study, it can be concluded that DNA isolation in blood spots results in the lowest and highest DNA levels of $577.5 \mu \mathrm{g} / \mu \mathrm{L}$ and $1683.5 \mu \mathrm{g} / \mu \mathrm{L}$, respectively while the average level of DNA in blood spots is $1094.45 \mu \mathrm{g} / \mu \mathrm{L}$. The lowest and highest DNA purity values are, respectively, 1.13 and 1.2 while the average 
value of DNA purity in blood spots is 1.18. DNA methylation in blood spots is visualized by $1 \%$ agarose gel electrophoresis between 150-300 bp. There is a significant correlation between percent methylation and age in male subjects but not in female subjects. This study has low external validity due to the small sample size.

\section{References}

1. Kumar A, Harish D, Singh A, Kulbhushan, Sunil Kumar GA. Unknown dead bodies: Problems and solutions. J Indian Acad Forensic Med. 2014;36(1):76-80.

2. Schmeling A, Dettmeyer R, Rudolf E, Vieth V, Geserick G. Forensic Age Estimation: Methods, Certainty and the Law. Dtsch Aerzteblatt Online. 2016;113:44-50.

3. Yi SH, Xu LC, Mei K, Yang RZ, Huang DX. Isolation and identification of age-related DNA methylation markers for forensic age-prediction. Forensic Sci Int Genet. 2014;11(1):117-25.

4. Huang Y, Yan J, Hou J, Fu X, Li L, Hou Y. Developing a DNA methylation assay for human age prediction in blood and bloodstain. Forensic Sci Int Genet.
2015;17:129-36

5. Vidaki A, Ballard D, Aliferi A, Miller TH, Barron LP, Syndercombe Court D. DNA methylation-based forensic age prediction using artificial neural networks and next generation sequencing. Forensic Sci Int Genet. 2017;28(2016):225-36.

6. LiX, LiW, Xu Y. Human age prediction based on DNA methylation using a gradient boosting regressor. Genes (Basel). 2018;9(9):424.

7. James SH, Eckert WG. Interpretation of bloodstain evidence at crime scenes. 2nd ed. Boca raton: CRC Press; 1999. p. 11-27.

8. Holmes EE, Jung M, Meller S, Leisse A, Sailer $\mathrm{V}$, Zech J, et al. Performance evaluation of kits for bisulfite-conversion of DNA from tissues, cell lines, FFPE tissues, aspirates, lavages, effusions, plasma, serum and urine. PLoS One. 2014;9(4):e93933.

9. Davegårdh C, Hall Wedin E, Broholm C, Henriksen TI, Pedersen M, Pedersen BK, et al. Sex influences DNA methylation and gene expression in human skeletal muscle myoblasts and myotubes. Stem Cell Res Ther. 2019;10(1):1-17.

10. Neidhart M. DNA Methylation and complex human disease. Oxford: Elsevier; 2016. p. 1-8. 